\title{
Práticas pedagógicas na educação infantil: contribuições da teoria histórico-cultural ${ }^{\star}$
}

\begin{abstract}
Resumo
Este texto apresenta as reflexões efetuadas no Projeto de Pesquisa "Práticas Pedagógicas na Educação Infantil: contribuições da Teoria Histórico-Cultural”, em que amparamos nossos estudos sobre práticas educativas e formação de professores nas elaborações da teoria histórico-cultural. O ponto de partida para a realização deste trabalho foi atribuirmos atenção aos procedimentos didáticos, conhecidos como "atividades"; identificamos registros (cartazes, cadernos e folhas avulsas) de crianças dos 32 núcleos de educação do Paraná. Intensificamos pesquisas relacionadas aos aspectos históricos das instituições de educação infantil para compreendermos a dinâmica do trabalho educativo na atualidade. Realizamos leituras dos clássicos da ciência da história e da teoria históricocultural, pois acreditamos que para a compreensão da organização da rotina (tempo e espaço) do trabalho pedagógico é necessário considerar as possibilidades de ensino intencional e sistematizado em uma perspectiva de humanização na educação infantil.
\end{abstract}

Palavras-chave: educação infantil; teoria-histórico-cultural; formação de professores.

\section{Pedagogical practices in children's education: the contributions of the Historical and Cultural Theory}

\begin{abstract}
Current analysis provides the discussions on the research project "Pedagogical Practices in Children's Education: The Contributions of the Historical and Cultural Theory" on the teachers' education and formation practices in their elaboration of the Historical and Cultural Theory. Special attention was given to didactic procedures, or "activities": children's registers were identified (posters, copybooks and sheets of paper) from 32 Education Nuclei of the state of Paraná, Brazil. In-depth research on the historical aspects of the institutions of Children's Education was undertaken to understand the dynamics of current educational work. Classics on the Science of History and on the Historical and Cultural Theory were read since the researchers were aware that the possibilities of intentional and systemized teaching within a humanized perspective in Children's Education were required for the comprehension of the organization of routine work (time and space) of pedagogical endeavor.
\end{abstract}

Keywords: Children's Education; Historical and Cultural Theory; Teachers' Formation.

\section{Introduction}

The conduction of the research project "Pedagogical Practices in Children's Education: The Contributions of the Historical and Cultural Theory", and our experience in teaching, participation and coordination of teachers' formation have made us aware that the day-to-day situation of institutions for Children's Education in current historical period is characterized by a continuous practice of procedures involving handouts and the so-called 'activities' to color and to 'sketch'.

Some procedures are frequently elaborated in stenciled or photocopied material so that children would paint the outlines of the illustrations. It is a pedagogical task with little or no real meaning for the students. In the case of 'non-free' didactic situations, they are as a rule fragmented, with themes dealing with commemorative dates. When they are somewhat connected with design, these pedagogical conditions are interrupted. In other words, the teacher develops a re-reading of a scene and later develops an action that does not suggest a follow-up or deepening of what had been commenced.

${ }^{\star}$ Group for Research and Studies in Early Childhood Education (GEEI) coordinated by Martha Chaves (State University of Maringa / UEM)

$\star \star$ Mailing address: Universidade Estadual de Maringá, Centro de Ciências Humanas Letras e Artes, Departamento de Teoria e Prática da Educação. Av. Colombo, 5790 - Zona 07. CEP: 87020-900 - Maringá, PR - Brasil. E-mail: mchaves@wnet.com.br.
It is well-known that these and other pedagogical interventions (fragmented and unconnected) are the usual children's experience in their first years of formal schooling. Due to the relevance of the first schooling years, the Historical and Cultural Theory was taken as a basis to assess pedagogical practices in Children's Education. Didactic resources were prepared and systemized to valorize teachers' formation and activities through current studies and propositions within the objectives of the research project.

\section{Studies and theoretical and methodological basis}

The point of departure for current research was the focus on didactic procedures, known as 'activities' that children undertake in Children's Education institutions. Posters, exercise books and sheets of paper were collected from 32 Regional Nuclei of Education of the state of Paraná, Brazil. The historical aspects of these institutions were researched to better understand the dynamics of current work. We also analyzed the Historical and Cultural Theory, or rather, the theoretical and methodological reference that foregrounds the analysis of didactic procedures and space composition in the aforementioned institutions.

Studies and propositions are based on the classics of the Science of History which foreground the premise that people and their ideas are the result of their material existence. The presupposition of such referential demonstrates that education does not explain itself. In 
other words, the phenomena are explained by the economic organization of society. Consequently, no phenomenon is understood in isolation.

The specificity of the organization of the routine and the analysis of didactic procedures prepared and undertaken by children demonstrate the need to consider the dynamics of current capitalist society. These basic items will contribute towards the understanding of the organization of the routine experienced by children in institutions of Children's Education.

What is explicitly or implicitly taught to children reveals the set of values predominant in society. For a better analysis of this issue, we may bring forth activities, such as 'commemoration dates', recurrent in educational institutions. For instance, the teacher guides the children to cut the image of an important person celebrated by the social media. The picture, taken from magazines focusing on famous people, is glued on a card with the legend "Happy Woman's Day". The above activity reveals the poor quality of children's experience, highly appreciated by capitalist society during these times in which unhappiness is a daily fact. These facts have helped us to develop current research and prepare our own didactic resources as a counterpart to sterile educational procedures, senseless and without any meaning.

As a theoretical and methodological possibility, the Historical and Cultural Theory is based on the Science of History and assesses society and routine in schooling institutions. Vygotsky's Imagination and Creativity in Childhood will be employed due to its themes on pedagogical practices undertaken in Children's Education institutions.

Throughout his works, Vygotsky underpins the relevance of the invention of necessities and provides our research with making available to children the elements of current cultural richness. The broadening and enriching of their experience imply necessarily in not limiting them to the experiences of their personal or local history, the only experience that capitalist society bequeaths them.

The above analysis reveals that the educational process makes possible experiences and procedures beyond one's home and that this perspective requires that children perceive the $21^{\text {st }}$ century as their own span of time, its art as their art, its music as their music. In other words, they must go beyond what capitalist society concedes them with all its limitations. In fact, it is the most important issue and challenge as researchers and educators who defend by all means school education.

When we reflect on such issues as teachers' formation and performance, it is imperative to analyze the political, economic and social conditions in which institutions and educators are inserted, underscoring a theoretical reference which is able to analyze and reveal such a setting, or rather, a decisive condition in the organization of the pedagogical task. It is highly important to perceive that at the beginning of the $21^{\text {st }}$ century, the conditions of millions of people is becoming worse and worse and poverty is immediately seen within the children's family and school environment. The reduction of learning favors children's poverty and annihilates their potential to learning and development.

In this context we base our arguments on the logic of the creation of needs and once more we have to underpin education through pedagogical interventions that express the valorization of the children's creative capacity. It is thus highly important to declare the political contents of the Historical and Cultural Theory based on education for a new society and in the formation of the 'new' man or the communist. As proposed by Vygotsky, humanization must be the starting point of the correct and adequate education. In such a perspective, the day-to-day of children, full of beauty and art, should be valorized. It should be underscored that, in so far as poverty predominates within its most varied forms, we should appreciate the political contents of the Historical and Cultural Theory, interpreted as the need to present and organize teaching as from the highest human expansions.

The study by Prestes (2012) and his translation of Imagination and Creativity in Childhood have been highly relevant. Following research by Vygotsky (2009), the creativity process does not occur spontaneously, from internal urges. In fact, creativity and manifestations of creativity are not the same for all children. The author argues that children's creativity may be organized and stimulated. "As we help children to organize their play, as we select and monitor their playful activities, in the same way we may also stimulate and guide their creative reaction" (VIGOTSKI, 2009, p. 91). According to the author, it is useful and possible to stimulate literary creativity in children; in other words, creativity may be developed, as current study underscores.

Walks, paintings, sketches, the organization of the milieu and of space in the Children's Education institution become important since "the best stimulation for children's creativity is the organization of children's life and environment that provides the generation of needs and possibilities for such a purpose" (VIGOTSKI, 2009, p. 92).

Within the same trend, Liublinskaia $(1973$, p. 17) remarks that the furniture in the premise, such as its "pretty arrangement" and "cleanliness", may stimulate positive feelings in the children. The author sees the above as a value from the educational point of view. The milieu and children's experience have a direct relationship with their feelings and stance within the present circumstances.

Not only people that surround the children influence them. The milieu, the objects used by the children and the toys that entertain them affect them. Children are influenced by the order that regulates their life, the talk of people around them, radio and TV programs they listen to; in fact, a great number of other factors, apparently insignificant, provokes reactions anyway (LIUBLINSKAIA, 1973, p. 15).

When the author refers to children's experience in the school and the organization of educational work, she writes:

The memory of children with an organized life is enriched by useful contents which accumulate successively and gradually. Their horizons widen and their observation and 
inquiring attitudes are formed. Their reasoning does not develop merely by specific types of activities such as in play, work or classroom, but also in their daily life where their brain has to function actively to understand the great number of unexpected phenomena and the constant difficulties that arise daily (LIUBLINSKAIA, 1973, p. 23-24).

The above quote reveals a basic issue in our analysis, a theoretical and methodological guideline by Vygotsky which is reaffirmed by other Historical and Cultural Theory researchers ${ }^{1}$ since it discusses the importance of organization in children's milieu. The organization of routine work, time and space is not only relevant but decisive to stimulate positive feelings and develop the artistic creativity in children through sketches, theatre and literature.

Creativity in literature or children's capacity to creativity implies in the organization of work within a perspective that valorizes the teachers' activities. It also implies in the intentionality of the educator and the organization of routine work - time and space - within the school. It is therefore essential to take into consideration the milieu or the role the milieu has.

In his highly important essay Fourth Lesson: the issue of the environment in Pedology, Vygotsky (2010, p. 695) states that

The environment acts as a source of development in children's development, in the development of personality and its characteristics. In this case, the environment does not have the role of circumstance but turns out to be a source of information.

According to the author, the environment has a direct relationship with the development of personality and feelings, since children acquire and rework what they see, hear and experience in a variety of ways in their reactions with the environment. The author adds that

Developed ideal forms exist in the environment. They have been worked out by mankind. They should arise at the end of development. Ideal forms affect children from the first steps towards the domination of the primary form. Throughout their development, children appropriate and transform into their interior acquisitions that which, at the beginning, was its way of external interaction with the environment (VIGOTSKI, 2010, p. 698).

The organization of routine work in the school (such as selecting music, poems and stories that should integrate permanently the task of Children's Education) requires studies and collective decision prior to the organization of strict pedagogical work. It favors the understanding that schools at all times and in all spaces should be filled

${ }^{1}$ The idea of organizing the environment is reinforced by a defense of the organization of teaching and direct activities of the teacher. Vasili Davidov may be mentioned with regard to this issue. Foregrounded on the writings of Vygotsky, he investigates the elaboration of the scientific concept in school children and states that education should take into account the technical progress and the social requirements in a given era. The author underscores the psychological and didactic unit for the understanding of the mechanism of learning and intellectual development. His Schooling and psychic development deals with one of the fundamental themes in Historical and Cultural Theory, with special reference to the teaching method, mediation and the importance of the teachers' activity in the education process. He also underscores the organization and implication of the teaching organization for children's learning and development. Similar to other studies on the theme, the author insists on the essentiality of the teaching organization and its direct relationship with psychic development (DAVÝDOV, 1978; DAVIDOV, 1988). with colors and sounds contrastingly to the hundreds of schools where books, toys and CDs are kept in the lockers of school coordinators or in some place out of reach of the children and far off their sight.

We understand that pedagogical interventions that deal with Children's Art and Literature enable linguistic and intellectual development of children. Therefore, didactic procedures have been prepared as examples of resources capable of furnishing teachers with tools and stimulate children for a type of knowledge that normally and generally lies outside their daily lives. Dictionaries, ${ }^{2}$ Booklets, ${ }^{3}$ Screen Boxes ${ }^{4}$ and Boxes of Enchantment and Life $^{5}$ are possibilities that reveal high level human workings.

We would like to underscore a special work on systematized information from the biographies of composers, painters, writers and playwrights. The study of literary works, travels, childhood and friends of the exponents of these areas is basic for the elaboration of planning and didactic procedures with and for children in Children's Education and in Primary Education. They immediately enrich the students' vocabulary and equip the children to develop higher psychological functions such as memory, attention, abstraction and thought. Consequently, there is a didactic and pedagogical meaning in the works of Vygotsky and Luria (1996) provided in Ape, Primitive Man and Child: Essays in the History of Behavior.

\section{Final considerations}

Current research corroborates the statement that schools for Children's Education may be excellent spaces of education. In other words, routine or the organization of time and space may be justified only when it is used as an education practice which is capable of promoting learning and develo-

${ }^{2}$ The dictionary Letras Vivas is a didactic resource which may be prepared with the children throughout the scholastic year. The choice of words for the dictionary may be undertaken from stories, poems, music, travels, terms that students are interested in knowing their meaning, or words placed as a challenge by the teacher in the classroom. The word is first registered; the teacher gives the definition taken from a didactic dictionary in use in the school; the children listen, read or register by writing or by sketches the meaning of the term; at a certain instance planned and organized by the teacher, the children collectively give the meaning to the word with the dictionary's definition as a starting point. The above didactic resource mobilizes the children to broaden their vocabulary.

${ }^{3}$ Booklets are didactic resources filled with texts, pictures, illustrations and information on a certain writer of literature, poetry, music and the plastic arts so that his or her artistic and cultural production is presented to the children. The Booklet may even give the biography of an author, musician, painter, sculptor, poet, inventor, researcher or any other relevant person in the history of mankind. The Biographic Booklet will be a collection of items in the life of a person under analysis and presented to the children.

${ }^{4}$ Screen Boxes are a didactic resource made of a paper or wooden box (or made from any other material) in which a three-dimension screen by an exponent of the visual arts is placed. Together with the reproduction, an image of the original screen is presented so that the children may observe the image and the result of work. The achievement, including planning, organization and preparation, may take several months and shows that during the period the children have acquired numberless experiences till the end of the preparation of the Screen Box. The whole process for the development of the didactic resource is proposed, organized and monitored by the teacher. The children participate actively in the preparation of the Screen Box under the guiding stance of the educator.

${ }^{5}$ The didactic resource Box of Enchantment and Life has to be prepared in groups. The group chooses an writer of literature, poems, music or arts to be studied. The Box involves "enchantments" which, as a rule, are represented by five themes: childhood, friends, work, travel and achievements on the acknowledgement or prize-giving that the exponent received during his professional life. Its aim is to represent "the life" of a specific exponent harvested from written material, photos and objects that characterize the different events of his history.

Fractal, Rev. Psicol., v. 27 - n. 1, p. 56-60, 2015 
pment in which playing and learning are the main aims, as has been discussed in other studies and essays (CHAVES, 2007, 2010a, 2010b; CHAVES et al, 2008).

We cannot shun the condition of poverty and suffering of millions of people. The conditions are revealed by the statistical data of Unicef (2011) on the mortality rates of children less than five years old in developing countries. Whereas in 2009 their number reached 3.3 million, there are no more than 100,000 in developed countries. According to the UNO, a child less than five years old dies every 20 seconds due to lack of drinking water, or rather, approximately 1.8 million deaths per year (NÚMEROS..., 2010, p. 55).

The poverty scenario has already been exploited by Marx (MARX; ENGELS, 1993) when he dealt with the capacity of the capitalist system for the production of poverty. The author described the life of children who started work in the early morning and ended by $11 \mathrm{pm}$, experiencing terrible hardships: “[...] their limbs weakened, their stature atrophied, their faces became livid, their being immerged into a stony torpor, horrible to bear" (MARX, 1994, p. 276).

We may also visualize darkened halls, slightly illuminated or ventilated classes, didactic and pedagogical materials deposited in dusty cabinets or merely stored in deposits next to cleaning material. They are places without toys, with cold cement floors, where children spend most of their time during the first year of their lives. The description may be of small relevance and may be discarded. It may also evidence the impairment within the schooling process which should be totally humanized and become full of creativity.

The above elements express the value that capitalist society attributes to children especially those from the working classes. Such educational institutions reveal how and what capitalist society reserves for school children and their teachers. The logic of the devaluation of knowledge expresses itself in scarcity or poverty, in physical structure and in educational activities, both weakened and impoverished.

The scenario in current historical process depicts a situation already denounced by Krupskaia ([19--]) and Makarenko ([19--], 1981) when they underscore that the children of the dominating classes take the reins of the historical process, whereas an education for subservience is the lot of the children of the worker classes. The above reveals the importance of schooling for those who defend the school as a possibility of humanization.

At present one of the challenges for educators is the re-evaluation of educational practices in schools. This is not an easy task due to the effort that capitalist system continually makes to place second the importance of knowledge. Researchers Saviani (2000, 2010), Duarte $(2001,2004,2010)$ and Facci (2004) already dealt with the issue. On the one hand, they insisted on the devaluation of the teachers' task and the denial of scientific knowledge; on the other hand, they underpinned the need of an education that assumed the responsibility of tea- ching knowledge historically accumulated by mankind. Duarte (2004) insists that the social media and official discourses should disseminate the relevance of education for the formation of creative and autonomous workers who will adequate themselves to the constant demands of capital. According to the author, through the apparent valorization of the school, education:

[...] hides the contradictions of society's neoliberal project, or rather, the contradictions of contemporary capital, and transforms the overcoming of social problems in an issue of individual mentality that would finally result from education (DUARTE, 2004, p. 47-48).

It is not an easy matter to understand that there is a relationship between education and labor, between capitalist economic dynamics and the schooling process. This is especially true in the case of Children's Education that seems to be totally disconnected from such issues. The reproduction of the logic of subordination in capitalist society is more easily perceived by us who work in the organization of pedagogical work routine in school institutions for children.

We are aware that undergraduate courses in Pedagogy and Psychology that deal with learning issues and with the development of children should have as their starting point a stance against impoverishment experienced by children and in defense of a type of education that enhances learning and the aesthetic sense. We hold that children and adults should appropriate the best that mankind prepares in Science, Philosophy and Arts. Routine, immediate experience, activities or the environment (taking children to the park, inviting them to play, organizing their time for feeding or sleeping), albeit apparently secondary actions, are, in our opinion, a means that enhance the creative process.

The above is based on the writing of Vygotsky (2009) on art and on studies by other researchers that share investigations and are in harmony with the Historical and Cultural Theory, besides being essential to deal with issues on Children's Education. We are sure that analyses of such a theoretical reference are the task of psychologists and pedagogues who have a direct relationship with professionals that work at this level of teaching and who defend schooling foregrounded on humanization and autonomy. Understanding the organization of pedagogical work and dealing with the formation and education of children presuppose the need to consider creativity in childhood as an issue that should be developed and thus taught.

\section{References}

CHAVES, M. Práticas educativas e formação em serviço: reflexões e desafios que se apresentam aos profissionais da infância. In: RODRIGUES, E.; ROSIN, S. M. (Org.). Infância e práticas educativas. Maringá: Eduem, 2007. p. 175-186.

CHAVES, M. Intervenções pedagógicas e promoção da aprendizagem da criança: contribuições da Psicologia HistóricoCultural. In: FAUSTINO, R. C.; CHAVES, M.; BARROCO, S. M. S. (Org.). Intervenções pedagógicas na educação escolar indígena: contribuições da Teoria Histórico-Cultural. 2. ed. Maringá: Eduem, 2010a. p. 71-86. 
CHAVES, M. Intervenções pedagógicas humanizadoras: possibilidades de práticas educativas com artes e literatura para crianças na Educação Infantil. In: CHAVES, M.; SETOGUTI, R. I.; MORAES, S. G. P. de (Org.). A formação do professor e intervenções pedagógicas humanizadoras. Curitiba: Instituto Memória, 2010b. p. 59-69.

CHAVES, M. et al. (Org.). Professores repensando a prática pedagógica: propostas, objetivos e conquistas coletivas. Maringá: Programa Interdisciplinar de Estudos de Populações, Laboratório de Arqueologia, Etnologia, UEM, 2008.

DAVIDOV, V. La enseñanza escolar y el desarrollo psíquico: investigación psicológica teórica y experimental. Trad. Marta Shuare. Moscú: Progreso, 1988.

DAVÝDOV, V. V. Tipos de generalización en la enseñanza. La Habana: Pueblo y Educación, 1978.

DUARTE, N. Educação escolar, teoria do cotidiano e a escola de Vigotski. 3. ed. Campinas, SP: Autores Associados, 2001. Coleção Polêmicas de Nosso Tempo, v. 55.

DUARTE, N. Vigotski e o "aprender a aprender": crítica às apropriações neoliberais e pós-modernas da teoria vigotskiana. 3. ed. Campinas, SP: Autores Associados, 2004. Coleção Educação Contemporânea.

DUARTE, N. Arte e formação humana em Vigotski e Lukács. In: DUARTE, N.; FONTE, S. S. D. Arte, conhecimento e paixão na formação humana: sete ensaios de pedagogia históricocrítica. Campinas, SP: Autores Associados, 2010. p. 145-162. Coleção Educação Contemporânea.

FACCI, M. G. D. Valorização ou esvaziamento do trabalho do professor?: um estudo crítico-comparativo da teoria do professor reflexivo, do construtivismo e da psicologia vigotskiana. Campinas, SP: Autores Associados, 2004.

KRUPSKAIA, N. Acerca de la educacion comunista: articulos y discursos. Tradução de V. Sanchez Esteban. Moscú: Ediciones em Lenguas Estranjeras, [19--].

LIUBLINSKAIA, A. A. O desenvolvimento psíquico da criança: dos 3 aos 7 anos. 3. ed. Tradução de Luis Marques Silva. Lisboa: Estampa, 1973. Biblioteca Básica de Cultura, 2.

MAKARENKO, A. S. O livro dos pais. Tradução de M. Rodrigues Martins. Lisboa: Livros Horizonte, [19--]. v. 2.

MAKARENKO, A. S. Conferências sobre educação infantil. Tradução de Maria Aparecida A. Vizzoto. São Paulo: Moraes, 1981.

MARX, K.; ENGELS, F. A ideologia alemã (I-Feuerbach). São Paulo: Hucitec, 1993.

MARX, K. O capital: crítica da economia política. 14. ed. Tradução de Reginaldo Sant'ana. Rio de Janeiro: Bertrand Brasil, 1994. v. I.

NÚMEROS. Veja, São Paulo, n. 2158, p. 55, 31 mar. 2010.

PRESTES, Z. R. Quando não é quase a mesma coisa: traduções de Lev Semionovitch Vigotski no Brasil. Campinas: Autores Associados, 2012.

SAVIANI, D. Pedagogia Histórico-Crítica: primeiras aproximações. 7. ed. Campinas, SP: Autores Associados, 2000. Coleção Polêmicas de Nosso Tempo, v. 40.

SAVIANI, D. O neoprodutivismo e suas variantes: neoescolanovismo, neoconstrutivismo, neotecnicismo (19912001). In: História das ideias pedagógicas no Brasil.
3. ed. rev. Campinas, SP: Autores Associados, 2010. p. 420424. Coleção Memória da Educação.

Unicef. Mortes de menores de 5 anos (milhões). Disponível em: <http://www.unicef.org/brazil/sowc2011/notageral.html>. Acesso em: 2 maio 2011

VIGOTSKI, L. S. Imaginação e criação na infância. Tradução de Zoia Prestes. São Paulo: Ática, 2009. Coleção Ensaios Comentados.

VIGOTSKI, L. S. Quarta aula: a questão do meio na pedologia. Tradução de Márcia Pileggi Vinha. Psicologia USP, São Paulo, v. 31, n. 4, p. 681-700, out./dez. 2010.

VYGOTSKY, L. S.; LURIA, A. R. Estudos sobre a história do comportamento humano: o macaco, o primitivo e a criança. Tradução de Lólio Lourenço de Oliveira. Porto Alegre: Artes Médicas, 1996.

Received: August 29, 2013 Accepted: November 1, 2014 